\title{
Graduate Attributes for Higher Education and Their Development in Bahrain
}

\author{
Fawzi A. Albalooshi ${ }^{1}$ \\ ${ }^{1}$ College of Information Technology, University of Bahrain, Kingdom of Bahrain \\ Correspondence: Fawzi Albalooshi, College of Information Technology, University of Bahrain, Sakhir Campus, \\ Kingdom of Bahrain. E-mail: albalooshi@batelco.com.bh/fawzi@itc.uob.bh
}

Received: June 27, 2013 Accepted: July 30, 2013 Online Published: August 16, 2013

doi:10.5539/ies.v6n9p23 URL: http://dx.doi.org/10.5539/ies.v6n9p23

\begin{abstract}
The general consensus in our society to the primary aim in obtaining a university degree is to improve one's wellbeing by obtaining a suitable well paid position after graduation. Many educationalists disagree with this goal to be the ultimate as stated by Haigh and Clifford (2010) 'there is more to life than doing a job. The graduates of our higher education system will be more than employees/employers, they will also be future leaders in our world and our neighbours and so affect our lives at all levels'. It is statements such as these that sparked the Graduate Attributes debate that has been going on over the past two decades and has recently intensified. This paper addresses Graduate Attributes as an issue that has been underestimated by higher education across the globe, but recently there have been some efforts to formalize and appropriately articulate them within the curriculum. The paper looks at Graduate Attributes as they are perceived by educators worldwide and presents some of the recent international efforts to establish attributes for higher education. The generic attributes that are suggested by a number of educational entities are presented and compared to find the commonalities of recommended attributes for future graduates. A discussion of the state of Graduate Attributes in Bahrain's higher education sector is carried out including a brief review and general observations of the attributes as published by a number of universities for Business and IT disciplines. The paper addresses the requirements of the National Authority for Qualifications and Quality Assurance of Education and Training in Bahrain and its possible impact on improving the state of Graduate Attributes offered by higher education institutions in Bahrain.
\end{abstract}

Keywords: Graduate Attributes, higher education, learning outcomes, quality assurance

\section{Introduction}

The general consensus in our society to the primary aim in obtaining a university degree is to improve one's wellbeing by obtaining a suitable well paid position after graduation. Many educationalists disagree with this goal to be the ultimate as stated by Haigh and Clifford (2010) 'there is more to life than doing a job. The graduates of our higher education system will be more than employees/employers, they will also be future leaders in our world and our neighbours and so affect our lives at all levels'. It is statements such as these that sparked the Graduate Attributes debate that has been going on over the past two decades and has recently intensified.

The term 'Graduate Attribute' [GA] by itself has been defined differently by educationalists; the most popular is the one from Bowden, Hart, King, Trigwell, and Watts (2000) who describe GAs as 'the qualities, skills and understandings a university community agrees its students would desirably develop during their time at the institution and, consequently, shape the contribution they are able to make to their profession and as a citizen'. On one hand Pitman and Broomhall (2009) argue that the term is abstract and demonstrates broad concepts for employability, lifelong learning, preparation for an uncertain future, and social justice, but on the other hand, the International Engineering Alliance [IEA] (2009) defines GAs as the 'set of individually assessable outcomes that are the components indicative of the graduate's potential to acquire competence to practise at the appropriate level. The Graduate Attributes are exemplars of the attributes expected of graduates from an accredited programme'. Barrie and Prosser (2004) argue that 'Graduate Attributes seek to describe the core outcomes of a higher education. In doing so, they specify an aspect of the institution's contribution to society and carry with them implicit and sometimes explicit assumptions as to the purpose and nature of higher education'. 
In this paper we explore this interesting issue in some depth. In section two we investigate a number of initiatives in establishing GAs at the national, discipline, and university levels. In section three these initiatives are compared and categorised according to the four pillars of education as laid out by UNESCO's International Commission on Education for the Twenty-first Century (Delors 1996a \& Delors 1996b). The state of GAs in Bahrain is investigated in section four. Section five discusses the impact of the National Authority for Qualification and Quality Assurance of Education and Training [QQA] (QQA, 2013) in Bahrain in motivating the education providers including higher education to establish GAs in line with international good practice. Concluding remarks are presented in section six.

\section{Graduate Attributes for the $21^{\text {st }}$ Century}

A review of the literature suggests two distinct approaches in which GAs are developed and implemented in higher education institutions. In the first, the attributes vary between universities within a country, as was reported by Barrie with regard to the Australian universities (Barrie 2006). They vary in the attributes included in the list and the level by which they are addressed. He reports that a similar situation was suggested by Drummond, Nixon, and Wiltshire (1998) regarding the UK higher education. In addition to the different institutional strategies for the establishment of GAs, Barrie (2006) asserts that there are even more differences in the understanding of academics of GAs resulting from different teaching and learning practices associated with them. He categorises their conception into four, and these are, precursor, complementary, translation, and enabling (The National Graduate Attributes Project 2011). In the second approach a set of GAs is well studied, understood, and made generic to be used as a base on a global scale by many universities and possibly across various disciplines. Capturing and analyzing GAs specifically designed for individual universities, colleges, and/or academic programmes can be a useless time consuming effort. Therefore, in this paper we focus on generic GAs that are properly investigated, well documented, and can be used on a global scale.

The Delors Commission report (Delors 1996a \& Delors 1996b) on Education for the $21^{\text {st }}$ Century published in 1996 stated that education throughout life is based on four pillars: learning to know, learning to do, learning to live together, and learning to be. In summary the four can be elaborated as follows: the learning to know is to combine broad knowledge with in depth on specific subjects; the learning to do is to acquire occupational skills and competencies to deal with many situations including working in teams; the learning to live together is by appreciating others, appreciation of interdependence, managing conflicts, respect for the values of pluralism, mutual understanding, and peace; and the learning to be is the ability to develop oneself, greater autonomy, judgement and personal responsibility.

During the past decade interesting effort to establish GAs at the National Level was initiated by the Scottish higher education institutions. In 2007 the Scottish Quality Assurance Agency (Haigh \& Clifford 2010; Jenkins 2009) established the following attributes for undergraduate studies:

- Critical understanding.

- Informed by current developments in the subject.

- An awareness of the provisional nature of knowledge, how knowledge is created, advanced and renewed, and the excitement of changing knowledge.

- The ability to identify and analyse problems and issues and to formulate, evaluate and apply evidence based solutions and arguments.

- An ability to apply a systematic and critical assessment of complex problems and issues.

- An ability to deploy techniques of analysis and enquiry.

- Familiarity with advanced techniques and skills.

- Originality and creativity in formulating, evaluating and applying evidence-based solutions and arguments.

- An understanding of the need for a high level of ethical, social, cultural, environmental and wider professional conduct.

This set is extended with the following three attributes for masters' students:

- Conceptual understanding that enables critical evaluation of current research and advanced scholarship.

- $\quad$ Originality in the application of knowledge.

- The ability to deal with complex issues and make sound judgments in the absence of complete data. 
This list of attributes has been extensively revised as a result of the Graduates for the $21^{\text {st }}$ Century Enhancement Theme (Hounsell 2011) that led the efforts to the establishment of new GAs for Scottish higher education in the $21^{\text {st }}$ century and their achievements. The new set of attributes has been developed as a result of a shared understanding between higher education establishments, a wide range of stakeholders, and international leading-edge practices. They are summarized as follows: lifelong learning; research scholarship and enquiry; employability and career development; global citizenship; communication and information literacy; ethical social, and professional understanding; personal and intellectual autonomy; and collaborative, teamwork and leadership.

Another initiative worthwhile reviewing is the GAs set by the IEA (2009) for their graduates. They define twelve GA profiles with differentiation characteristics for engineers, technologists, and technicians and they are: engineering knowledge, problem analysis, design/development of solutions, investigation, modern tool usage, the engineer and society, environment and sustainability, ethics, individual and team work, communication, project management and finance, and lifelong learning.

Haigh and Clifford (2010) in their paper published by Brooks eJournal of Learning and Teaching widen the GA debate further and propose an interesting set of attributes that expand on the career related aspects. These attributes are, responsible citizens, capable citizens, compassionate citizens, self-aware citizens, ecoliterate citizens, cosmopolitan citizens, and employed citizens. The career related aspects include: retrieve and manage information and knowledge, get results, think creatively and innovate, demonstrate expertise in their special discipline(s), communicate, work in a team, act as an effective leader or manager, develop autonomously, commit to quality and social justice, adapt to change, and learn from experience.

According to Barrie (2006) and as reported by Drummond et al. (1998) despite serious efforts and funding during the 1990s in the UK, implementing GAs was not successful. Intensive research and development in GAs has also been initiated in New Zealand such as that funded by the National Centre for Tertiary Teaching Excellence - AKO AOTEAROA (2012) that aims to explore current policy and practice related to GAs in higher education. Similarly, in Australia a number of GAs projects at the national level have been initiated, such as, the National Graduate Attributes Project (Institute for Teaching and Learning 2011).

\section{Comparison of Generic Graduate Attributes}

In the previous section we introduced a number of initiatives to establish GAs such as the IEA and the Scottish higher education community. In this section we compare those two and the set proposed by Haigh and Clifford (2010) using the four pillars of education defined by Delors (1996a \& 1996b) as a guide. Table 1 below presents the three set of GAs against the four pillars of education.

Table 1. Comparing the Graduate Attributes

\begin{tabular}{llll}
\hline $\begin{array}{l}\text { Delors' Four Pillars of } \\
\text { Education }\end{array}$ & IEA & Scottish-HE & Haigh and Clifford
\end{tabular}

\section{First Pillar - learning to}

know: to combine broad knowledge within depth on specific subjects

\begin{tabular}{|c|c|c|c|}
\hline $\begin{array}{l}\text { Second Pillar - learning to } \\
\text { do: to acquire } \\
\text { occupational skills and } \\
\text { competencies to deal with } \\
\text { many situations including } \\
\text { working in teams }\end{array}$ & $\begin{array}{l}\text { Problem Analysis; } \\
\text { Design/ development of } \\
\text { solutions; Investigation; } \\
\text { Modern Tool Usage; } \\
\text { Individual and Team } \\
\text { work; Communication; } \\
\text { Project Management and } \\
\text { Finance }\end{array}$ & $\begin{array}{l}\text { Research, Scholarship } \\
\text { and Enquiry; } \\
\text { Communication and } \\
\text { Information Literacy; } \\
\text { Personal and Intellectual } \\
\text { Autonomy; and } \\
\text { Collaborative, } \\
\text { Teamwork and } \\
\text { Leadership }\end{array}$ & $\begin{array}{l}\text { Retrieve and Manage } \\
\text { Information and } \\
\text { Knowledge; Get Results; } \\
\text { Think Creatively and } \\
\text { Innovate; Communicate; } \\
\text { Work in a Team; Act as } \\
\text { an effective leader or } \\
\text { manager }\end{array}$ \\
\hline $\begin{array}{l}\text { Third Pillar - learning to } \\
\text { live together: is by } \\
\text { appreciating others, } \\
\text { appreciation of }\end{array}$ & $\begin{array}{l}\text { The Engineer and } \\
\text { Society; Environment and } \\
\text { Sustainability; Ethics }\end{array}$ & $\begin{array}{l}\text { Global Citizenship; } \\
\text { Ethical, Social, and } \\
\text { Professional } \\
\text { Understanding }\end{array}$ & $\begin{array}{l}\text { Responsible Citizens; } \\
\text { Capable Citizens; } \\
\text { Compassionate Citizens; } \\
\text { Self-aware Citizens; }\end{array}$ \\
\hline
\end{tabular}
Demonstrate Expertise in their Special Discipline(s)
Engineering Knowledge
Employability and Career Development

(1)


interdependence, managing

conflicts, respect for the

values of pluralism, mutual

understanding, and peace
Ecoliterate Citizens;

Cosmopolitan Citizens; and Employed Citizens. Committed to quality and social justice

Fourth Pillar - learning to

be: is the ability to develop oneself, greater autonomy, judgement and personal responsibility
Lifelong Learning Lifelong Learning

Develop Autonomously,

Adapt to Change, and

Learn from Experience

For the first pillar 'learning to know', all three agree that graduates must have subject knowledge, in addition the Scottish-HE set adds 'career development' that opens the path for future development in the field of study as advancements are inevitable, but could also be linked to the fourth pillar.

In the second pillar the similarities are many, such as, teamwork, communication skills, and leadership skills. Some of the IEA attributes for this pillar seem to be specific to engineers such as problem analysis and design and modern tool usage. In the other two sets the attributes are more broadly stated to encompass various disciplines such as, 'Research, Scholarship, and Enquiry' and 'Communication and Information Literacy' in the Scottish-HE set; and 'Retrieve and Manage Information and Knowledge', 'Get Results', and 'Think Creatively and Innovate' in the Haigh and Clifford's set.

For the third education pillar, IEA's recommended attributes describe the GAs with the society and environment from an engineer's perspective rather than as a person or citizen. The Scottish-HE attributes seem to better fulfill this pillar as it describes its graduates as global citizens with humanity in mind in dealing with the surrounding environment. Haigh and Clifford's proposed attributes for this pillar are the most extensive as it specifically listed the recommended ethos.

For the fourth pillar, both IEA and the Scottish-HE set had similar views in that the graduate must have the ability and interest to learn in his field and from experience, but Haigh and Clifford's attributes seem to better fulfill the pillar requirements as they include the ability for a graduate to 'Adapt to Change' which can be an advantage in an unpredictable environment and to 'Develop Autonomously' that recognizes personal differences and preferences in human development.

Having compared the three sets of GAs it is fair to highlight that the IEA set was specifically established for engineers, but it has an international scope, whereas the Scottish-HE set was developed to be generic in that it encompasses all disciplines offered by higher education institutions in Scotland and would serve as the basis for the set of GAs to be offered. Similar to the Scottish-HE set, Haigh and Clifford's set is also generic to be adopted by all disciplines in higher education. More importantly it is interesting to note that educators from different disciplines and parts of the world greatly agree on the qualities, skills, and understandings of the future graduates.

\section{The State of Graduate Attributes in Bahrain's Higher Education Sector}

As part of this study we reviewed the GAs as published (on the universities' official web sites) by some of our local universities in Bahrain. We refrain from publishing the particulars of this study in this paper for confidentiality reasons of the universities included in the study. On the other hand the reader can easily access the universities' web sites to view their published statements related to their intentions' for graduates. Analyses and comparison of the published GAs lead us to a similar conclusion to that commented by Barrie (2006) regarding the situation of Australian universities in that they vary in the attributes (stated as aims, goals, or outcomes) included in their lists and level by which they are addressed, and are often not well defined. Our general observations on the selected eight academic programmes from four different universities are as follows:

- The form of presentation is not uniform within a university and across universities, in that the learning outcomes are sometimes part of the dean's message, sometimes they are stated in the mission statement, and in other times they are stated as programme intended learning outcomes;

- the terminology used is not uniform even within the same university, words used to refer to the attributes include aims, goals, objectives, and outcomes;

- the attributes are sometimes set at the college level and in other times at programme level; 
- colleges/programmes within the same university have different sets of non-discipline related outcomes;

- the first, second, and fourth of Delors' pillars have been addressed at varying levels of depth and breadth, but for the third 'learning to live together' a couple of colleges/programmes failed to totally address it, though it was addressed by another college/programme within the same university;

- and outcomes are set at varying levels of depth and breadth within the same university and across universities.

\section{The National Authority for Qualifications and Quality Assurance of Education and Training}

In Bahrain an attempt to discuss and debate GAs at the national level has so far not taken place, nor are there any guidelines or regulations governing their establishment. Most universities freely specify their intended learning outcomes for each programme rather than have generic university wide outcomes, though mission statements at university and college levels briefly state the institution's intensions or expectations for their graduates. Some universities have revised their academic programme(s) learning outcomes to suite accreditation requirements they are seeking.

The QQA, previously known as the Quality Assurance Authority for Education and Training [QAA], started academic programme reviews in 2009 which require universities to submit a programme specification for each programme being reviewed as part of their self-evaluation report. The programme specification template available in the programme review handbook (QQA 2009a) specifically requests the institution to specify the intended learning outcomes for each academic programme being offered in terms of: knowledge and understanding, subject-specific skills, thinking skills, and general and transferable skills. This request is in line with international norms and was accommodated by all higher education institutions for all reviewed programmes. The programme review framework has a major indicator on academic standards of the graduates that an institution must satisfy to obtain a confidence judgement. Similarly, the institutional review framework (QQA 2009b) has a major theme on academic standards which is made up of six indicators two of which are directly related to GAs.

Furthermore, the QQA has recently established its National Qualifications Framework [NQF] previously known as the Bahrain Qualification Framework [BQF] (BQF 2010) which is expected to evaluate every qualification offered in Bahrain and once approved it is listed to be valid at its intended level as specified by the provider. The framework specifies ten levels with the bachelor's degree setting at level eight. For each level a set of expected learning outcomes is specified including knowledge, skills, and competencies. For the knowledge part a learner is expected to have theoretical understanding and practical application of the subject/discipline which maps to Delors' first pillar. For the skills part a learner is expected to have gained field related generic cognitive skills and communication, ICT, and numeracy skills which maps to Delors' second pillar. The competencies expected include, context, autonomy and responsibility, learning to learn, and insight which maps to Delors' third and fourth pillars of education. Table 2 shows the NQF/BQF level eight descriptors (BQF 2010) as an example of the type of attributes expected of a bachelor's degree graduate. The NQF/BQF is currently being piloted with a range of institutions for different qualification levels.

The measures taken by the QQA to ensure rigorous academic standards and appropriate GAs as part of its institutional and programme reviews and qualifications approval requirements is expected to encourage all providers to revise their GAs to meet the standards set by the QQA in its review and qualifications frameworks.

Table 2. NQF Level Eight Descriptors

Knowledge that covers and integrates most of the principal areas, features, boundaries, terminology and conventions of a subject/discipline.

A critical understanding of the principal theories, principles and concepts.

$\begin{array}{ll} & \text { Theoretical } \\ \text { Knowledge } & \text { Understanding }\end{array}$

Detailed knowledge and understanding in one or more specialisms, some of which is informed by, or at the forefront of, a subject/discipline.

Knowledge and understanding of the ways in which the subject/ discipline is developed, including a range of established techniques of enquiry or research methodologies.

Practical

Application
Use a range of the principal skills, practices and/or materials associated with a subject/ discipline. 
Use a few skills, practices and/or materials which are specialised, advanced or at the forefront of a subject/discipline.

Execute a defined project of research, development or investigation and identify and implement relevant outcomes.

Practice in a range of professional level contexts that include a degree of unpredictability and/or specialism.

Critically identify, define, conceptualise and analyse complex/professional level problems and issues.

Offer professional level insights, interpretations and solutions to problems and issues.

Generic Critically review and consolidate knowledge, skills, practices and thinking Cognitive Skills in a subject/discipline.

Demonstrate some originality and creativity in dealing with professional level issues.

Make judgements where data/information is limited or comes from a range of sources.

Skills

Use a wide range of routine skills and some advanced and specialized skills in support of established practices in a subject/discipline, for example:

Make formal presentations about specialised topics to informed audiences.

Communication, ICT and Communicate with professional level peers, senior colleagues and specialists

Numeracy

Use a range of software to support and enhance work at this level and specify refinements/improvements where applicable to software to increase effectiveness.

Interpret, use and evaluate a wide range of numerical and graphical data to set and achieve goals/targets.

Use advanced skills to conduct research, or advanced technical or

Context professional activity, accepting accountability for all related decision making; transfer and apply diagnostic and creative skills in a range of contexts.

\begin{tabular}{lll}
\cline { 1 - 1 } Competence & $\begin{array}{l}\text { Autonomy and } \\
\text { Responsibility }\end{array}$ & $\begin{array}{l}\text { Act effectively under guidance with qualified practitioners; lead multiple, } \\
\text { complex and heterogeneous groups. }\end{array}$ \\
\cline { 2 - 3 } & $\begin{array}{l}\text { Learn to act in variable and unfamiliar learning contexts; learn to manage } \\
\text { Learning to Learn }\end{array}$ & $\begin{array}{l}\text { learning tasks independently, professionally and ethically. } \\
\text { Insight }\end{array}$ \\
\cline { 2 - 2 } & $\begin{array}{l}\text { Express a comprehensive, internalized, personal world view, manifesting } \\
\text { solidh others. }\end{array}$ \\
\hline
\end{tabular}

\section{Concluding Remarks}

This paper addresses GAs as an important factor that affects the generations of graduates to come and their well-being. The key discussions and efforts surrounding GAs are highlighted in section two in an effort to present the latest developments in the field. GAs from selected international initiatives were benchmarked against the four pillars of education defined by Delors as part of a UNESCO initiative as presented in section three. By highlighting their similarities and differences it became evident that educators from different disciplines and parts of the world mostly agree on the set of GAs future generations should acquire from higher education. In section four we present our observations to the state of GAs in higher education in Bahrain based on a set of selected higher education institutions. Their published GAs are benchmarked against Delors' four pillars of education. The observations are meant to bring to the attention of higher education institutions and other entities responsible for higher education the importance of adequately establishing GAs, be it at the 
institutional or national level. In section five we briefly discuss the Bahraini government's effort to assure the quality of education in the kingdom through its initiative to establish the QQA in 2008 which is currently executing its second cycle of reviews at all education levels including schools, training/vocational, and higher education providers. The recent linking of the Bahrain Qualifications Framework to the QQA is expected to ensure that GAs as set by the NQF/BQF (BQF 2010) are met by the education providers for their qualifications to be formally recognized by QQA. Furthermore, the measures taken by the QQA to ensure rigorous academic standards and appropriate GAs as part of its institutional and academic programme reviews are expected to encourage all providers to revise their GAs to meet international good practice.

\section{References}

AKO AOTEAROA, National Centre for Tertiary Teaching Excellence. (2012). Graduate outcomes: Are they driving learning? And who knows about them? Retrieved October 30, 2012, from http://akoaotearoa.ac.nz/graduate-outcomes

Bahrain Qualifications Framework. [BQF] (2010). Retrieved June 25, 2013, from http://bqf.tamkeenpartners.net/

Barrie C. S. (2006). Understanding What We Mean by the Generic Attributes of Graduates. Higher Education, 51(2), 215-241. Springer 2006. http://dx.doi.org/10.1007/s10734-004-6384-7

Barrie, S. C., \& Prosser, M. (2004). Generic Graduate Attributes: Citizens for Uncertain Future. Higher Education Research \& Development, 23(3), 243-246, August.

Bowden, J., Hart, G., King, B., Trigwell, K., \& Watts, O. (2000). Generic Capabilities of ATN University Graduates. Canberra: Australian Government Department of Education, Training and Youth Affairs. Retrieved October 24, 2012, from http://www.clt.uts.edu.au/ATN.grad.cap.project.index.html and http://www.clt.uts.edu.au/TheProject.htm\#one

Delors, J. (1996a). UNESCO Task Force on Education for the Twenty-first Century. Retrieved November 6, 2012, from http://www.unesco.org/delors/

Delors, J. (1996b). Learning: the treasure within. Retrieved October 24, 2012, from $\mathrm{http}: / / \mathrm{www}$.unesco.org/new/en/education/themes/leading-the-international-agenda/rethinking-education/the -four-pillars-of-learning/

Drummond, I., Nixon, I., \& Wiltshire, J. (1998). Personal transferable skills in higher education: The problems of implementing good practice. Quality Assurance in Education, 6(1), 19-27. http://dx.doi.org/10.1108/09684889810200359.

Haigh Martin, \& Clifford Valerie (2010). Widening the Graduate Attribute Debate: A Higher Education for Global Citizenship. Brooks eJournal of Learning and Teaching, 2(5), February.

Hounsell, D. (2011). Graduates for the 21st Century: Integrating the Enhancement Themes, Institutional Activities. The Quality Assurance Agency for Higher Education 2011. Retrieved October 24, 2012, from http://www.enhancementthemes.ac.uk/docs/publications/graduates-for-the-21st-century-institutional-activiti es.pdf and http://www.enhancementthemes.ac.uk/enhancement-themes/completed-enhancement-themes/graduates-forthe-21st-century/graduates-for-the-21st-century-institutional-activities.pdf

Institute for Teaching and Learning. (2011). The National Graduate Attribute Project. Retrieved October 30, 2012, from http://www.itl.usyd.edu.au/projects/nationalgap/projectbackground/overview.htm

International Engineering Alliance [IEA]. (2009). Graduate Attributes and Professional Competencies Version 2'. $\quad$ Retrieved $\quad$ October 24, 2012, from http://www.washingtonaccord.org/IEA-Grad-Attr-Prof-Competencies-V2.pdf

Jenkins A. (2009). Research-Teaching Linkages: Enhancing Graduate Attributes. The Quality Assurance Agency for Higher Education, 2009 Retrieved July 31, 2013, from http://www.enhancementthemes.ac.uk/docs/publications/research-teaching-linkages-enhancing-graduate-att ributes-overview-report.pdf

National Authority for Qualifications and Quality Assurance of Education and Training [QQA]. (2009a). Higher Education Review Unit, Programme Review Handbook. National Authority for Qualifications and Quality Assurance of Education and Training, Bahrain, 2009. 
National Authority for Qualifications and Quality Assurance of Education and Training [QQA]. (2009b). Higher Education Review Unit, Institutional Review Handbook. National Authority for Qualifications and Quality Assurance of Education and Training, Bahrain, 2009.

National Authority for Qualifications and Quality Assurance of Education and Training [QQA]. (2013). Retrieved June 25, 2013, from http://www.qaa.edu.bh/

Pitman, T., \& Broomhall, S. (2009). Australian universities, generic skills and lifelong learning. International Journal of Lifelong Education, 28(4), 439-458. http://dx.doi.org/10.1080/02601370903031280

The National Graduate Attributes Project. (2011). Integration and assessment of Graduate Attributes in $\begin{array}{lllll}\text { curriculum. } & \text { Retrieved } & \text { October } & 31, & \text { 2012, }\end{array}$ http://www.itl.usyd.edu.au/projects/nationalgap/introduction.htm

\section{Copyrights}

Copyright for this article is retained by the author(s), with first publication rights granted to the journal.

This is an open-access article distributed under the terms and conditions of the Creative Commons Attribution license (http://creativecommons.org/licenses/by/3.0/). 